Chirurgia (2017) 112: 172-177

No. 2, March - April

Copyright $\odot$ Celsius

\title{
Surgical Treatment of an Aneurysmal Bone Cyst with Avascular Bone Graft
}

\author{
Alexandru Ulici ${ }^{1,2}$, Catalin Nahoi ${ }^{1}$, Madalina Carp ${ }^{1}$, Ioan Fodor ${ }^{1}$, Cristina Dinu ${ }^{1}$ \\ ${ }^{1}$ Grigore Alexandrescu Emergency Hospital for Children, Bucharest, Romania \\ ${ }^{2}$ Carol Davila University of Medicine and Pharmacy, Bucharest, Romania
}

Corresponding author:

Alexandru Ulici, MD

6, lancu de Hunedoara Boulevard

BI H4, Sc1, et 1, ap 5, district 1

Bucharest, Romania

E-mail: alexandruulici@me.com

Received: 16.11.2017

Accepted: 20.01.2017

\section{Rezumat}

Tratamentul chirurgical al unui chist osos anevrismal cu grefon nevascularizat

Introducere: Chistul osos anevrismal este o formațiune tumoralã osoasã solitarã, expansivã şi liticã cel mai adesea întâlnitã în a doua decadã de viațã, mai frecvent la bãrbați decât la femei $(2: 1)$. Acestea pot apãrea la nivelul oricãrui os, fiind cel mai des întâlnit la nivelul metafizei oaselor lungi ale membrelor inferioare. Deşi este o formațiune tumoralã benignã, chistul anevrismal poate avea o evoluție localã agresivã şi poate cauza o scãdere importantã a rezistenței osoase. Se poate prezenta pentru durere, apariția unei mase tumorale sau aparitia unei fracturi pe os patologic. Traditional aceste leziuni au fost tratate chirurgical (chiuretaj sau rezecție şi grefare osoasã) cu o ratã de recidivã de aproximativ $20 \%$. Deoarece rezecția osoasã poate conduce la defecte osoase, deformãri sau lezarea functiei membrului afectat în ultima vreme se utilizeazã scleroterapie percutanã cu agenți fibrozanți alcoolici. Prezentare de caz: Vã prezentam cazul unui pacient de 14 ani, prezentat pentru durere şi deformare la nivel $1 / 3$ distale a antebrațului drept cu debut insidios şi agravate în ultima perioadã. În urma investigațiilor clinice, paraclinice şi histopatologice s-a stabilit diagnosticul de chist osos anevrismal cubitus drept. Deorece scleroterapia nu este încã disponibilã în clinica noastrã, inițial s-a practicat o biopsie excizionalã cu chiuretarea leziunii. Tumora a avut în continuare o evoluție agresivã postoperator, astfel încât s-a decis rezecția osoasã şi reconstrucție cu grefon peronier nevascularizat. Concluzie: Pacientul prezinta o evoluție postoperatorie pe termen scurt şi mediu favorabilã, cu dispariția durerilor şi reluarea 
funcției segmentului afectat. Radiologic se poate observa integrarea grefonului osos, precum şi lipsa semnelor de recidivã localã.

Cuvinte cheie: chist osos anevrismal, biopsie, grefă peroneală avasculară, reconstrucție osoasă

\begin{abstract}
Background: Aneurysmal bone cyst is a solitary bone tumor, expansile and lytic most often seen in the second decade of life, more frequently in men than in women (2: 1). They can occur in any bone, most common in the metaphysis of the long bones of the lower limbs. Although it is a benign tumor formation, aneurysmal cysts may have an aggressive local evolution and can cause a significant decrease in bone strength. The pacient may present local pain, the appearance of local deformation due to a tumor mass or occurrence of pathological fractures. Traditionally these lesions were treated surgically (curettage or resection and bone grafting) with a relapse rate of about $20 \%$. Because bone resection may lead to bone defects, deformations or damage in the affected limb's function, lately the preferred treatement percutaneous sclerotherapy using fibrosing alcoholic agents. Case report: We present the case of a 14 year old pacient submitted for pain and deformity at the distal third of the right forearm with insidious onset and exacerbated lately. Following clinical investigations, laboratory and histopathology he was diagnosed with aneurysmal bone cyst of the right ulna. Since sclerotherapy is not available in our clinic, we initially performed an excisional biopsy with curettage of the lesion. Because the tumor still had an aggressive postoperative evolution, we decided for a bone resection and reconstruction using an avascular peroneal graft. Postoperative, the patient presents a favorable short and medium term evolution, the disappearance of pain and resumed function of the affected segment. Radiologically bone graft integration can be observed, with no evidence of local recurrence.

Conclusion: Although modern tehniques for treating anurysmal bone cyst include either injecting fibrosing alcoholic agents or resection and grafting using vascular bone graft, the traditional tehnique described by Merle d'Aubigne which implies the usage of avascular bone graft is still heplful, leading to succesful results especially in the upper limbs.
\end{abstract}

Key words: aneurysmal bone cyst, biopsy, avascular peroneal graft, bone reconstruction

\section{Background}

An aneurysmal bone cyst (ABC) is a solitary, expasile, radiolucent lesion ussually located in the metaphyseal region of the long bones. Seen much less often than simple bone cysts, they sum up to $1 \%$ of all primary bone tumors sampled for biopsy(prima). A primary $\mathrm{ABC}$ occurs most commonly in teenagers $(80 \%)$. Aneurysmal bone cysts can be found throughout the skeleton. The most common sites are the femur, tibia, spine, humerus, pelvis, and fibula, with approximately half of the cases reported occuring in the long bones of the extremities. Although they usually involve the metaphyseal region, aneurysmal bone cysts may on occasion cross the physis into the epiphysis or may extend into the diaphysis. Almost $20 \%$ of aneurysmal bone cysts involve the spine, can be located anywhere between the axis and the sacrum and may lead to cord compression or spinal deformities $(1,2,3,4)$.

Aneurysmal cysts may represent either a primary bone tumor or a secondary response (arteriovenous malformation) to the destructive effects of an underlying primary tumor. Development of an aneurysmal bone cyst as a secondary response is supported by the 
association of aneurysmal cysts with other primary lesions, such as nonossifying fibromas, fibrous dysplasia, chondroblastomas, giant cell tumors and simple bone cysts. Over $30 \%$ of aneurysmal cysts are believed to be secondary to other lesions, thus once the diagnosis is considered, a thorough preoperative evaluation is necessary, and careful pathologic studies are needed to ensure whether it is a primary lesion or secondary to a different bone tumor (2).

Aneurysmal bone cysts spread rapidly, thus the clinical presentation includes localized pain of several weeks' or months' duration, tenderness. The lesions are usually located eccentrically and tend to break out of the bone and expand. This leads to palpable swellings and protuberances. If the cysts involve the spine, progressive enlargement may affect the spinal cord or nerve roots, resulting in neurologic deficits such as motor weakness or sensory disturbance. Spinal involvement mandates urgent intervention.

Radiologically, the aneurysmal bone cyst is an eccentrically located, metaphyseal osteolytic lesion with minimal marginal sclerosing or septum formation. The classic radiographic feature of aneurysmal bone cysts was described by Jaffe as a periostal "blowout" or balloonedout lesion that is outlined by a thin shell of periosteal new bone formation. The periosteal reaction appears to be aggressive, and the lesion may be mistaken for an aggressive or malignant tumor.

Taking in consideration the location and radiographic findings the aneurysmal bone cyst should differentiated from giant cell tumor, simple bone cyst, but also from a teleangiectatic osteosarcoma.

Aneurysmal bone cysts can have an expansive and aggressive growth and can rapidly reach considerable size. Although spontaneous healing of aneurysmal bone cysts has been reported, it is very uncommon. As a rule, how ever, when the diagnosis of aneurysmal bone cyst is made, active treatment is recommended. A biopsy should always be performed before starting the surgical treatment as aneurysmal bone cysts can develop from another tumor (5).
Management includes combinations of embolization, curettage with or without bone grafting, cementing of the cavity, reconstructive surgery- bone resection and grafting using vascular or avascular bone graft, and most recently sclerotherapy $(4,6)$.

Curettage with or without bone grafting of aneurysmal cysts has been the standard treatment for many years. Unfortunately, this tumor has a high incidence of local recurrence (14\% to $59 \%)$ after curettage and other treatments have been indicated $(4,6)$.

En-bloc resection of the tumor, as it rarely extends to the epiphysis, followed by reconstruction using a vascular or avascular bone graft is usually preferable. Because bone resection may lead to bone defects, deformations or damage in the affected limb's function, lately the preferred treatement percutaneous sclerotherapy using fibrosing alcoholic agents $(5,6,7)$.

The use of polidocanol as an endovenous sclerosing agent to treat varicose veins dates from the 1960s, and has been recently shown to be effective in the treatment of ABCs. Sclerosants act by causing damage to the endothelium of vessels and starting a coagulation cascade that results in thrombosis. Overall, sclerotherapy has emerged as a promising treatment that could eventually replace previous methods, which may be associated with considerable morbidity. However, it is not widely accepted and its efficacy remains to be verified in large series of patients $(8,9)$.

\section{Case report}

Patient A.R. aged 14 presented in our clinic for pain and deformation in the distal third of the right forearm. The symptoms had an insidious onset in the last few months, but were aggravated lately. A X-Ray of the forearm, in PA and $\mathrm{L}$ views, was performed and it revealed an osteolytical bone lession in the distal third of the ulna that produced the thinning and deformation of the cortical bone ("blown out bone" aspect) (Fig. 1). Conservative treatment and careful monitoring was decided. Within a 


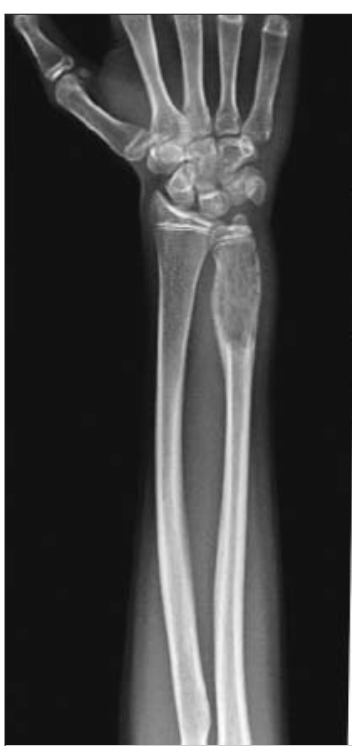

Figure 1. First X-Ray

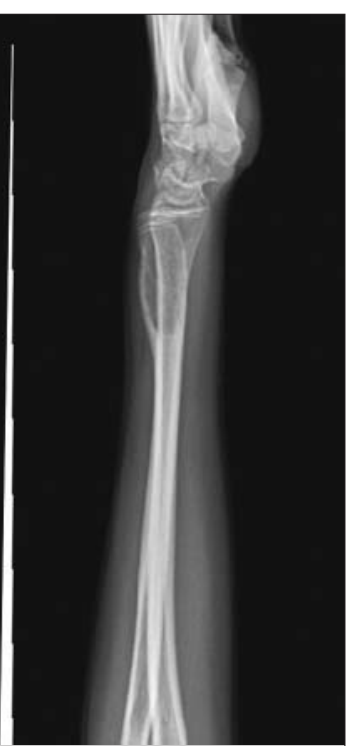

Figure 2. 1 month follow-up X-Ray

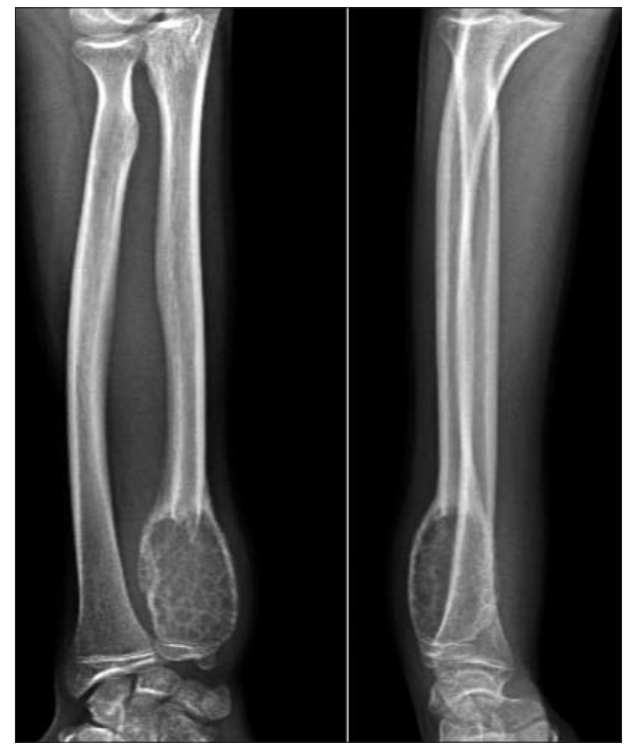

month the tumor had grown significantly (Fig. 2), therefore an excisional bone biopsy with curettage of the lesion was performed. After the histopathological exam a final diagnosis was established: Aneurysmal bone cyst of the right ulna.

Because the tumor still had an aggressive postoperative evolution, ilustrated by the growth of the lesion on the follow-up X-Rays (Figs. 3,4,5) and also by the clinical aspects, large deformation of the distal third of the right forearm (Figs. 6,7,8), a second surgery was decided upon.
A preoperative CT was performed and it revealed an oval osteolytical bone lession distal third of the ulna, approximately $55 \times 32$ $\mathrm{mm}$, presenting fluid density, with cortical bone lysis and that doesn't expand beyond the physis into the epiphysis making more surgical options available (Fig. 9). A 3D reconstruction was performed, that highlighted the lytical and fluid aspects of the cyst (Fig. 10,11).

As sclerotherapy was not yet available in our clinic the selected treatment method was an en-bloc resection and reconstruction using an avascular peroneal bone graft. The tumor was

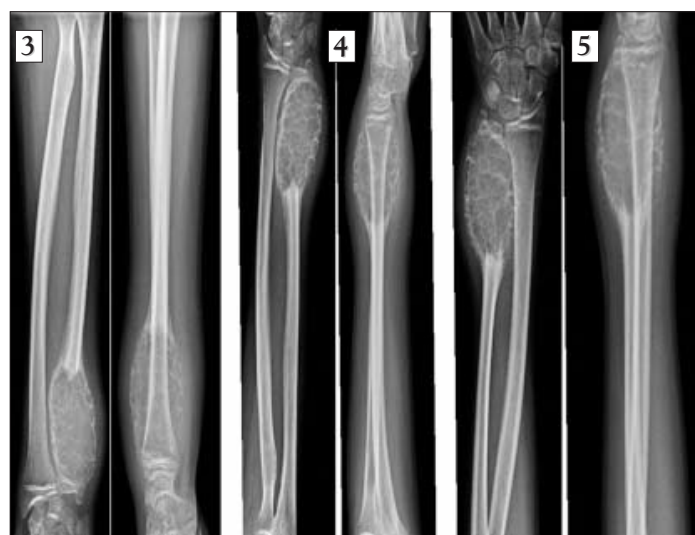

Figure $\mathbf{3 , 4 , 5}$. X-Ray evolution

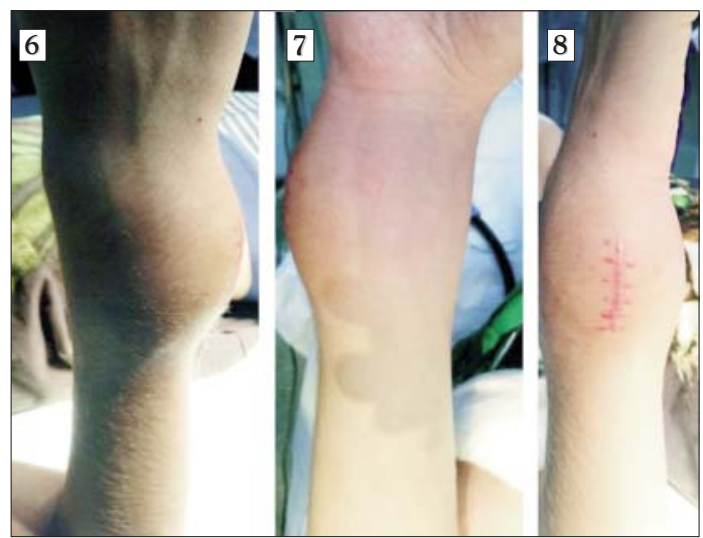

Figure $\mathbf{6 , 7 , 8}$. Clinical aspects of the forearm 


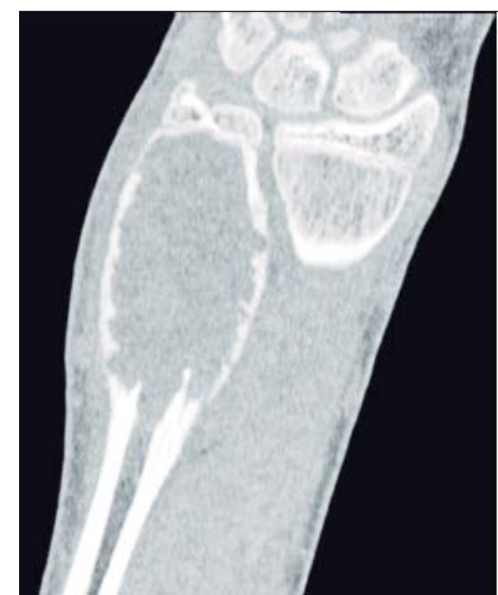

Figure 9. CT image of the cyst
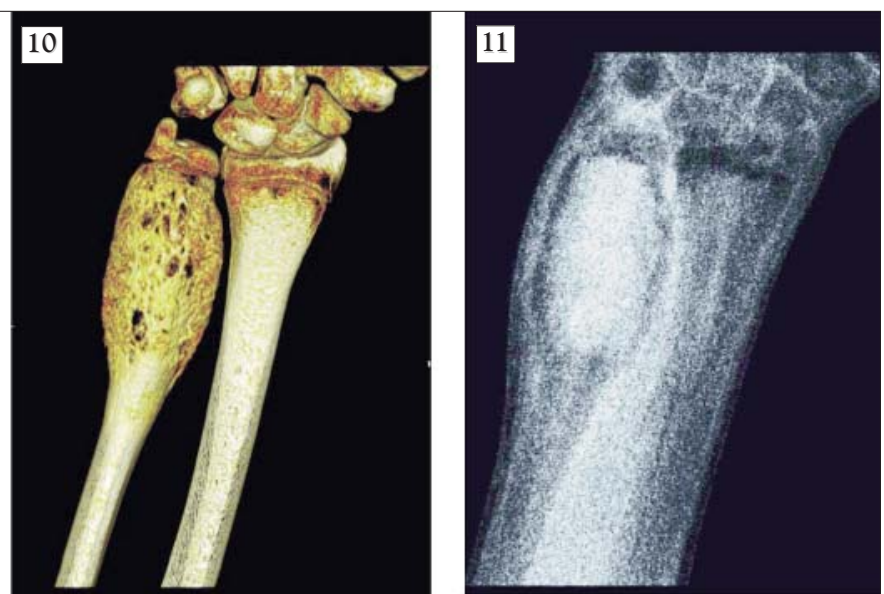

Figures 10,11. 3D reconstruction excised, distally right above the physis and proximally $3 \mathrm{~cm}$ above the lesion, and sent to the histology department. Special care was taken during the surgery as to conserve the growth plate and the periosteum. The reconstruction of the bone defect was performed using an avascular graft harvested from the ipsilateral peroneal bone. After performing the reconstruction the graft was fixed in place using a Kirschner wire and the forearm was placed in a cast for 1 month. A postoperative $\mathrm{X}$-Ray was performed the next day after surgery and showed the excision of the cyst and the reconstruction of the bone defect (Fig.12).

Within the next months the patient had constant follow-ups, consisting of careful clinical examination and forearm X-Rays, which revealed bone formation and graft integration (Fig. 13). The 6 month follow-up
X-Ray showed complete integration of the graft and almost complete healing of the donor site (Fig. 14).

The one year postop X-Ray showed healing and integration of the graft in the distal ulna (Fig. 15) therefore the removal of the $\mathrm{K}$ wire was performed. Postoperative evolution was good, with normal function of the limb and no local pain.

An X-Ray was performed 3 months after the removal of the $\mathrm{K}$ wire, showing good local evolution(fig. 16).

\section{Conclusion}

In conclusion, the fact that postoperative, the patient presents a favourable short and medium term evolution, the disappearance of pain and resumed function of the affected

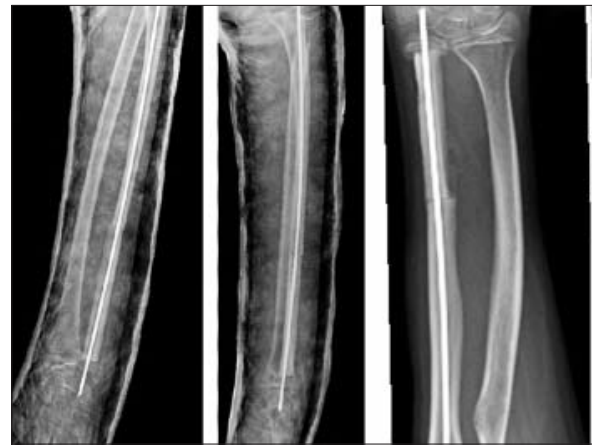

Figure 12. Postop X-Ray
Figure 13. Follow-up X-Rays

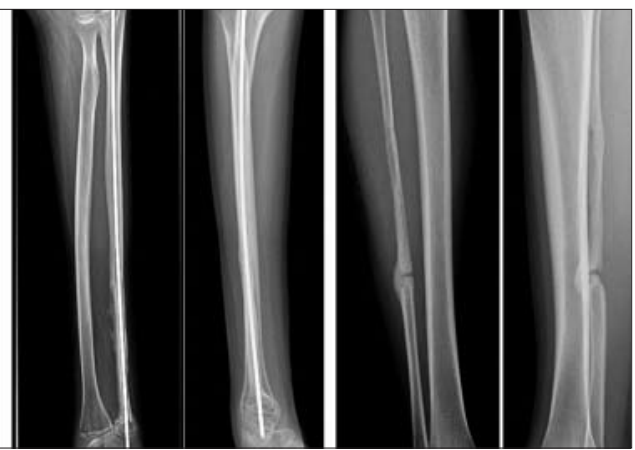

Figure 14. 6 month follow-up 


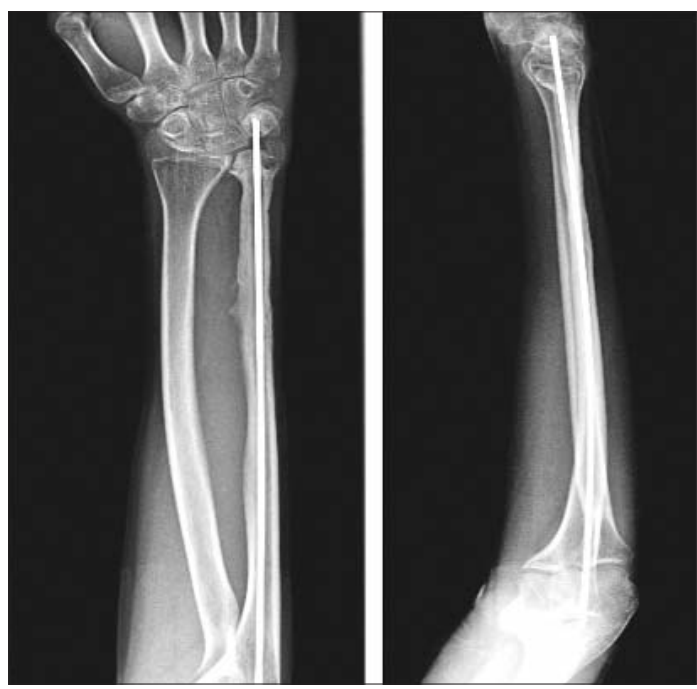

Figure 15. 1 year postop X-Ray

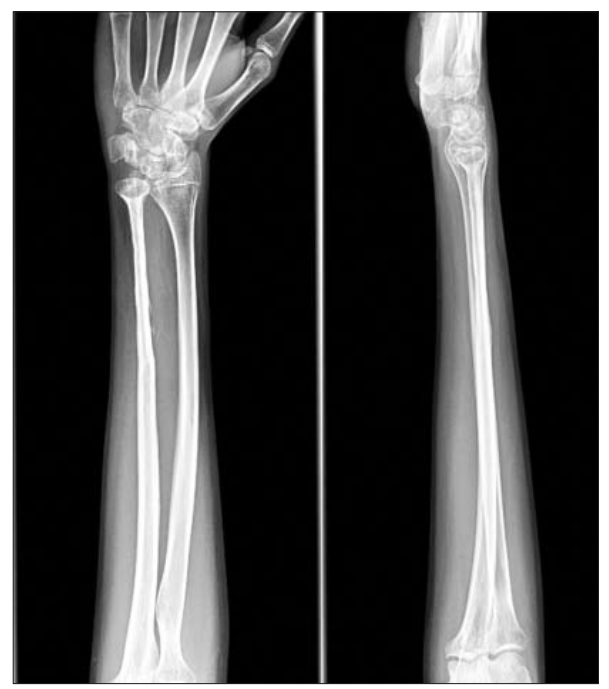

Figure 16. 3 month after removal of $\mathrm{K}$ wire X-Ray segment correlated with radiologically observed bone graft integration and with the absence of local recurrence demonstrates that although modern techniques for treating aneurysmal bone cyst include either injecting fibrosing alcoholic agents or reconstruction using vascular bone graft, the traditional technique described by Merle d'Aubigne which implies the usage of avascular bone graft is still helpful, leading to successful results especially in the upper limbs.

\section{Conflicts of interest}

No interest conflict to report.

\section{References}

1. Herring JA. Tachdjan's Pediatric Orthopaedics 5th edition; Ed Elsevier; 2014. p. 1088-1092.
2. Weinstein SL, Flynn JM. Lovell and Winter's Pediatric Orthopedics; 7th edition; Ed Wolters Kluwer; 2013. p 529-531

3. Mendenhall WM, Zlotecki RA, Gibbs CP, Reith JD, Scarborough MT, Mendenhall NP. Aneurysmal bone cyst. Am J Clin Oncol. 2006;29(3):311-5.

4. Güven M, Demirel M, Ozler T, Bașsorgun IC, Ipek S, Kara S. An aggressive aneurysmal bone cyst of the proximal humerus and related complications in a pediatric patient. Strategies Trauma Limb Reconstr. 2012;7(1):51-6. doi: 10.1007/s11751-012-0132-9.

5. Grzegorzewski A, Pogonowicz E, Sibinski M, Marciniak M, Synder $M$. Treatment of benign lesions of humerus with resection and nonvascularised, autologous fibular graft. Int Orthop. 2010;34(8): 1267-72. doi: 10.1007/s00264-009-0911-1. Epub 2009 Nov 27.

6. Park HY, Yang SK, Sheppard WL, Hegde V, Zoller SD, Nelson SD, et al. Current management of aneurysmal bone cysts. Curr Rev Musculoskelet Med. 2016;9(4):435-444.

7. Han YF, Fan XD, Su LX. Percutaneous sclerotherapy with absolute alcohol to treat aneurysmal bone cyst of the frontal bone. J Craniofac Surg. 2015;26(2):456-8. doi: 10.1097/SCS.0000000000001378.

8. Brosjö 0, Tsagozis P. Treatment of an aggressive aneurysmal bone cyst with percutaneous injection of polidocanol: a case report. J Med Case Rep. 2014;8:450. doi: 10.1186/1752-1947-8-450.

9. Batisse F, Schmitt A, Vendeuvre T, Herbreteau D, Bonnard C. Aneurysmal bone cyst: A 19-case series managed by percutaneous sclerotherapy. Orthop Traumatol Surg Res. 2016;102(2):213-6. 